\title{
Potato Yield and Quality Not Changed by Foliar-applied Methanol
}

\author{
E.B.G. Feibert ${ }^{1}$ \\ Malheur Experiment Station, Oregon State University, 595 Onion Avenue, \\ Ontario, OR 97914
}

S.R. James ${ }^{2}$

Central Oregon Agricultural Research Center, Oregon State University, 850 Northwest Dogwood Lane, Madras, OR 97741

K.A. Rykbost ${ }^{3}$

Klamath Experiment Station, Oregon State University, 6941 Washburn Way, Klamath Falls, OR 97603

\author{
A.R. Mitchell ${ }^{4}$ \\ Central Oregon Agricultural Research Center, Oregon State University, 850 \\ Northwest Dogwood Lane, Madras, OR 97741

\section{C.C. Shock ${ }^{3}$} \\ Malheur Experiment Station, Oregon State University, 595 Onion Avenue, \\ Ontario, OR 97914
}

\section{Additional index words. Solanum tuberosum, water use, tuber}

\begin{abstract}
Previously published research suggests that the yield and water-use efficiency of C-3 plants can be enhanced through foliar-applied methanol. Potatoes (Solanum tuberosum L. cv. Russet Burbank) grown in Oregon at Klamath Falls, Madras, and Ontario were subjected to repeated foliar methanol treatments during the 1993 season. Methanol was applied at $20 \%, 40 \%$, and $80 \%$ concentration with Triton X-100 sticker-spreader at $0.1 \%$, and methanol was applied at $20 \%$ and $40 \%$ without Triton $X-100$. Methanol had no effect on tuber yield, size distribution, grade, or specific gravity at any location. Tuber stem-end fry color showed no methanol response at the two locations where it was measured. Soil water potential (measured at Madras and Ontario) showed no difference in water-use efficiency between methanol-treated and nontreated potato plants.
\end{abstract}

Nonomura and Benson (1992a, 1992b) reported increases in growth and yield of several C-3 species in response to foliar-applied methanol under high light intensity and high temperature conditions. They also reported increased leaf turgidity and lower water use associated with foliar applications of methanol. Enhanced water-use efficiency would be very important in the Pacific Northwest, since most water available to the potato plants is applied via irrigation.

The objective of this trial was to evaluate whether 'Russet Burbank' potatoes would respond to foliar-applied methanol with increased tuber yield in high light intensity environments typical for irrigated potato production

Received for publication 7 Oct. 1994. Accepted for publication 21 Feb. 1995. Oregon State Univ. technical paper no. 10,609. Use of trade names does not imply endorsement of the products named nor criticism of similar ones not named. The cost of publishing this paper was defrayed in part by the payment of page charges. Under postal regulations, this paper therefore must be hereby marked advertisement solely to indicate this fact.

${ }^{1}$ Faculty Research Assistant.

${ }^{2}$ Senior Faculty Research Assistant.

${ }^{3}$ Professor.

${ }^{4}$ Assistant Professor. in the Pacific Northwest. The trial compared tuber yield and quality and soil water potential between methanol-treated and nontreated potato plants.

'Russet Burbank' potatoes were planted with $60-\mathrm{g}$ seed pieces (spaced $30 \mathrm{~cm}$ apart at Klamath Falls, Ore., and $20 \mathrm{~cm}$ apart at Madras and Ontario, Ore.) in rows $0.91 \mathrm{~m}$ apart and grown according to standard commercial production practices under solid-set sprinkler irrigation systems. The three Oregon sites were widely spaced and climatically distinct. The soils were Poe fine sandy loam (sandy, mixed, mesic Typic Durochrepts) at Klamath Falls (southern), Madras loam (fine-loamy, mixed, mesic Xerollic Durargid) at Madras (central), and Owyhee silt loam (coarse-silty, mixed, mesic, Xerollic Camborthid) at Ontario (eastern).

To establish toxicity level, aqueous methanol solutions $[10 \%, 20 \%, 40 \%$, and $80 \%$ methanol (v/v) with and without Triton X-100 surfactant (Sigma Chemical Co., St. Louis)] were sprayed at 600 liters.ha ${ }^{-1}$ on potato plants at Ontario using a backpack sprayer with 8002 nozzles (Teejet nozzles; Spraying Systems Co., Wheaton, Ill.). Sprays were applied at 3:00 PM on 18 June 1993. The experimental design was a randomized complete block with four replications.
To evaluate tuber yield and grade, five treatments and a nonsprayed control were arranged in three randomized complete-block experiments with four replications each at Klamath Falls and Madras and five at Ontario. Methanol was applied at $20 \%, 40 \%$, and $80 \%$ in an aqueous solution with Triton X-100 sticker-spreader at $0.1 \%$ and at $20 \%$ and $40 \%$ without Triton X-100. Potato plants in all treated plots at each location received three methanol applications.

The methanol solutions were applied with a backpack sprayer at 608 liters.ha ${ }^{-1}$ with 8002 LP nozzles at Ontario and at 187 liters.ha ${ }^{-1}$ with 8002 nozzles at Klamath Falls, and with a $\mathrm{CO}_{2}$ sprayer at 187 liters.ha ${ }^{-1}$ with 8002 nozzles at Madras. Plots were sprayed between 1:00 and 4:00 PM at Ontario and between noon and 1:00 PM at Klamath Falls and Madras. Air maxima for the application dates ranged from 21 to $34 \mathrm{C}$. The monthly average air maxima ranged from 21 to $29 \mathrm{C}$ for the months when methanol was applied.

Soil water potential was measured daily at Madras and Ontario by using granular matrix sensors (GMS; model 200SS, Watermark Soil Moisture Sensors; Irrometer Co., Riverside, Calif.) centered at $0.20-\mathrm{m}$ depth and offset $0.15 \mathrm{~m}$ from the hill center. One or two GMS were placed in each of four replications at Madras and four in each of three replications at Ontario. Sensors were previously calibrated to soil water potential (Eldredge et al., 1993). At Klamath Falls, irrigations were run on a fixed schedule, and at Madras, the accumulated potato evapotranspiration $\left(\mathrm{ET}_{\mathrm{c}}\right)$ was replaced at each irrigation. At Ontario, we aimed to keep the soil water potential wetter than -60 $\mathrm{J} \cdot \mathrm{kg}^{-1}$ by replacement of the accumulated $\mathrm{ET}_{\mathrm{c}}$. $\mathrm{ET}_{\mathrm{c}}$ was determined by AgriMet (U.S. Bureau of Reclamation, Boise, Idaho) weather stations at Madras and Ontario. Tubers were harvested from the middle two rows in each four-row plot on 3, 4, and 5 Oct. at Ontario, Madras, and Klamath Falls, respectively. Tubers were graded by market class and weight according to U.S. Dept. of Agriculture grade and size standards. A representative tuber subsample was stored for later determination of tuber specific gravity and stem-end fry color (Shock et al., 1994) in early November at Ontario and in mid-December at Madras. Tuber specific gravity was determined at the time of grading at Klamath Falls.

The preliminary trial produced no leaf necrosis or toxicity symptoms. Lack of leaf toxicity contrasts with observations by Nonomura and Benson (1992a), but agrees with the lack of toxicity on peppermint (Mentha $\times$ piperita L.) (Mitchell et al., 1994).

Tuber yield ranged from 38 to 43 thha ${ }^{-1}$ at Klamath Falls, 65 to 68 t.ha ${ }^{-1}$ at Madras, and 48 to $55 \mathrm{t} \cdot \mathrm{ha}^{-1}$ at Ontario. Neither tuber yield nor grade were influenced by foliar-applied methanol at any site. Methanol did not influence stem-end fry color or specific gravity. Our yield results are consistent with others on muskmelon (Cucumis melo L.), watermelon (Citrullus vulgaris Schrad.), and tomato (Lycopersicon esculentum Mill.) (Hartz et al., 1994); peppermint (Mitchell et al., 1994); cot- 
ton (Gossypium hirsutum L.) (Mauney and Gerik, 1994); snapbean (Phaseolus vulgaris L.) (Lee and Rowland, 1994); grape (Vitis vinifera L.) (Dami et al., 1994); orange (Citrus sinensis Osbeck) (Wutscher, 1994); and other crops (McGiffen et al., 1994).

Soil water potential was similar for the methanol-treated and control potatoes. The soil water potential data do not suggest any greater water-use efficiency by potato plants treated with foliar-applied methanol than by the controls. These results agree with those of Mitchell et al. (1994), who found that foliarapplied methanol failed to improve the wateruse efficiency of peppermint.

The weather during the 1993 growing season at the three Oregon locations was cooler than normal for these sites, but probably typical of commercial potato-producing areas in the Pacific Northwest. The failure to obtain a response at these sites suggests that it is un- likely that methanol can be used commercially to improve potato yield or quality.

\section{Literature Cited}

Dami, I., C. Stushnoff, and R. Hamman. 1994. Physiological and biochemical responses of grapevines to methanol. HortScience 29:91. (Abstr.)

Eldredge, E.P., C.C. Shock, and T.D. Stieber. 1993. Calibration of granular matrix sensors for irrigation management. Agron. J. 85(6):1228-1232.

Hartz, T.K., K.S. Mayberry, M.E. McGiffen, M LeStrange, G. Miyao, and A. Baameur. 1994. Foliar methanol application ineffective in tomato and melon production. HortScience 29:1087.

Lee, E.H. and R.A. Rowland. 1994. Field studies of agrimethanol on photosynthesis and yield of snapbean cv. Top Crop. Plant Growth Regulat. Soc. Amer. Quarterly 22:28.

Mauney, J.R. and T.J. Gerik. 1994. Evaluating methanol usage in cotton, p. 39-40. In: D.J. Herber and
D.A. Richter (eds.). Proc. 1994 Beltwide Cotton Conf. Natl. Cotton Council, Memphis. vol. 1.

McGiffen, M.E., J. Manthey, A. Baameur, R.L. Greene, B.A. Faber, A.J. Downer, and J. Aguiar. Field tests of methanol as a crop yield enhancer. HortScience 29:212. (Abstr.)

Mitchell, A.R., F.J. Crowe, and M.D. Butler. 1994. Plant performance and water use of peppermint treated with methanol and glycine. J. Plant Nutr.17(11):1955-1962.

Nonomura, A.M. and A.A. Benson. 1992a. The path of carbon in photosynthesis: Improved crop yields with methanol. Proc. Natl. Acad. Sci. vol. 89, p. 9794-9798.

Nonomura, A.M. and A.A. Benson. 1992b. The path of carbon in photosynthesis: Methanol and light. Res. Photosynthesis 3:914-991.

Shock, C.C., T.D. Stieber, J.C. Zalewski, E.P. Eldredge, and M.D. Lewis. 1994. Potato tuber stem-end fry color determination. Amer. Potato J. 71:77-88.

Wutscher, H.K. 1994. The effect of methanol on orange fruit quality. HortScience 29:1025. (Abstr.) 